\title{
Perkembangan Sosial Anak Usia Dini Melalui Teman Sebaya
}

\author{
Aprilia Elsye Melinda ${ }^{1}$, Izzati2 $^{2}$ \\ 1,2 Jurusan Pendidikan Guru Pendidikan Anak Usia Dini, Universitas Negeri Padang, Padang,, Indonesia
}

\section{ART I CLE IN F O}

Article history:

Received 16 January 2021

Revised 02 February 2021

Accepted 01 April 2021

Available online 25 April 2021

\section{Kata Kunci:}

perkembangan sosial, teman sebaya

Keywords:

social development, peers

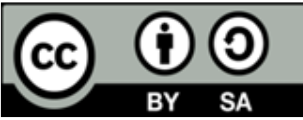

This is an open access article under the CC BY-SA license.

Copyright () Universitas Pendidikan Ganesha. All rights reserved.

\begin{abstract}
A B S T R A K
Perkembangan sosial merupakan salah satu aspek penting pada perkembangan yang harus diutamakan dalam pembelajaran melalui bermain dengan teman sebaya. Keadaan anak didik saat ini yang belum mampu bersosialisasi dengan teman sebaya. Penelitian ini bertujuan menganalisis perkembangan sosial anak usia dini melalui teman sebaya. Jenis penelitian ini mengunakan deskriptif kualitatif. Respon dalam penelitian ini adalah seluruh siswa kelas B4 Taman Kanak-kanak, guru dana kepala sekolah. teknik pengumpulan data menggunakan wawancara, observasi dan dokumentasi, teknik tersebut digunakan untuk memperoleh informasi perkembangan sosial anak memalui teman sebaya. Teknik analisis dalam penelitian menggunakan analisis kualitatif. Hasil penelitian ini menunjukan bahwa teman sebaya dapat membantu perkembangan sosial anak seperti anak dapat mematuhi peraturan dan membantu teman dalam keadaan seperti belajar dan juga berbagi terhadap teman. Maka dapat disimpulkan teman sebaya memberikan pengaruh terhadap perkembangan sosial anak usia dini. Implikasi penelitian ini diharapkan dapat menjadi evaluasi dalam mengembangkan hubungan sosial anak dengan teman sebaya.
\end{abstract}

\section{A B S T R A C T}

Social development is one of the important aspects of development that must be prioritized in learning through playing with peers. The current state of students who have not been able to socialize with peers. This study aims to analyze the social development of early childhood through peers. This type of research uses descriptive qualitative. The responses in this study were all students of grade B4 Kindergarten, teachers and principals. data collection techniques using interviews, observation and documentation, these techniques are used to obtain information on children's social development through peers. The analysis technique in this research uses qualitative analysis. The results of this study indicate that peers can help children's social development as children can obey the rules and help friends in situations such as learning and also sharing with friends. So it can be concluded that peers have an influence on the social development of early childhood. The implications of this research are expected to be an evaluation in developing children's social relationships with peers.

\section{Pendahuluan}

Pendidikan Anak Usia Dini (PAUD) merupakan salah lembaga pendidikan yang memiliki peran penting dalam membangun semua potensi anak-anak (Junanto \& Kusna, 2018; Sum \& Taran, 2020). Usia dini merupakan usia cemerlang yang memiliki arti penting dan penting karena masa ini merupakan masa pembentukan masa depan anak (KhoiruzzadiM et al., 2020; We \& Fauziah, 2020). Keberhasilan dalam membina atau mengarahkan anak-anak sejak awal merupakan derajat kemajuan anak bagi masa depan anak, namun lagi-lagi ketidakmampuan memberikan arahan, kepedulian, dan pengarahan merupakan kegagalan bagi kehidupan anak di kemudian hari (Agustin, 2020; Meilanie, 2020). Manusia pada dasarnya adalah makhluk yang bersahabat yang membutuhkan kolaborasi dengan sesama untuk memenuhi kebutuhan sehari-hari (Andangjati et al., 2021; Negara et al., 2019). Salah satu aspek perkembangan di Taman Kanak-kanak adalah sosial anak (sosial anak). Perkembangan sosial anak usia dini menjadi kan ciri khas seorang anak bagaimana cara anak bersosial dengan lingkungan terutama dengan teman sebanyanya (Maola \& Lestari, 2021; Musyarofah, 2018). Lingkungan akan memberikan dampak baik atau

Copyright (c) Universitas Pendidikan Ganesha. All rights reserved 
buruk terhadap aspek perkembangan anak terutama perkembangan sosial anak yang dapat dilihat melalui anak berinteraksi dengan teman sebaya.

Permasalahan saat ini yaitu anak yang kurang bersosialisasi dengan teman sebaya tidak di bantu oleh guru untuk bermain dengan temannya (Izza, 2020; Yuniarni, 2016). Anak yang kurang bersosialisasi dengan teman sebaya lebih banyak pada waktu istirahat bersama orang tua (Mardiah \& Ismet, 2021; Pebriana, 2017). Anak usia dini menjalin hubungan pertemanan dengan teman sebaya mulai dengan umur 2 tahun. Melalui komunikasi dengan teman sebaya akan terbentuk hubungan sosial dengan teman sebaya (Ramadhani \& Fauziah, 2020). Berdasarkan hasil observasi awal yang dilakukan di Taman Kanak-kanak 01 Sangir, di temukan perkembangan sosial anak belum berkembang secara optimal. Hal ini di sebabkan karena anak masih di awasi dan di tunggu di luar kelas dan anak hanya berteman dengan teman yang dikenal saja. Selain itu, hanya beberapa anak yang mampu untuk berinterksi sosial dengan teman sebaya juga anak yang mengajak teman untuk bermain bersama saat istirahat. Metode yang dilakukan untuk mengembangkan sosial anak hanya melalui permainan individu tanpa diberikan permainan kelompok yang akan membantu perkembangan sosial anak, dengan bermain secara berkelompok tidak akan menimbukan kebosanan anak seperti bermain peran itu dapat membantu perkembangan sosial anak dengan teman sebaya (Cakra et al., 2016; Rahmadianti, 2020a).

Perkembangan sosial dianggap sebagai faktor penting dalam perkembangan anak, terutama mengingat pentingnya kesiapan sekolah anak (Ramadhani \& Fauziah, 2020). Perkembangan sosial terdiri dari hubungan yang dimiliki seseorang dengan orang lain, tingkat pengendalian diri, dan motivasi serta ketekunan yang dimiliki seseorang selama suatu kegiatan (Ramadhani \& Fauziah, 2020; Sukatin et al., 2020). Perkembangan sosial pada anak terkait dengan perasaan anak-anak tentang diri mereka sendiri (seperti kepercayaan diri, selalu takut, bersemangat untuk belajar, bangga dengan budaya mereka, takut akan kesalahan), bagaimana mereka berperilaku (seperti terus-menerus berkelahi, mudah marah, mampu menangani konflik), dan bagaimana mereka berhubungan dengan orang lain, terutama orang-orang yang berarti bagi mereka (misalnya, orang tua, guru, dan teman) (Rahmawati \& Latifah, 2020; Yuniarni, 2016). Interaksi yang baik antara anak dan teman sebaya sangat penting karena dapat memberikan banyak perasaan, pengalaman, dan pembelajaran secara sosial dan emosional sehingga memungkinkan anak untuk memiliki tingkat perkembangan sosial-emosional yang tinggi (Sirois et al., 2019).

Temuan penelitian sebelumnya menyatakan perkembangan sosial dengan teman sebaya banyak memberikan dampak baik untuk perkembangan anak (Saputro \& Pardiman, 2012; Yanti \& Marimin, 2017). Anak yang melakukan interaksi dengan teman sebaya dapat membantu anak dalam mentaati aturan yang ada di sekolah, anak dapat berbagi dengan teman nya dan anak juga dapat menunjukan sikap tatakrama dengan teman nya maupun lingkungan sekitar (Andangjati et al., 2021; Fadhilah \& Mukhlis, 2021). Belum adanya kajian penelitian mengenai perkembangan sosial anak usia dini melalui teman sebaya Taman Kanak-kanak 01 Sangir. Penelitian sebelumnya mengkaji perkembangan sosial pada anak sekolah dasar. Kebaruan penelitian ini yaitu menganalisis bagaimana perkembangan sosial anak usia dini melalui teman sebaya, sehingga penelitian ini dapat diasumsikan akan melengkapi penelitian sebelumnya yang sudah ada. Penelitian ini bertujuan untuk menganalisis perkembangan sosial anak usia dini melalui teman sebaya di Taman Kanak-kanak 01 Sangir. Diharapkan kajian ini dapat menjadi evaluasi dalam meningkatkan kemampuan sosial anak.

\section{Metode}

Jenis penelitian ini adalah penelitian deskriptif dengan pendekatan kuantitatif. metode kualitatif ini metode yang digunakan untuk memahami fenomena yang dialami subjek penelitian, contohnya perilaku. Kemudian dideskripsikan dengan kalimat dan menggunakan beberapa metode ilmiah. Responden dalam penelitian ini yaitu siswa kelas B4 Taman Kanak-kanak Negeri 01 Sangir Solok Selatan, guru kelas, guru sentra dan kepala sekolah. Kajian ini diarahkan pada riset yang random sampling, yang mengandung makna bahwa setiap populasi pemeriksaan sebagai komponen masyarakat memiliki kesempatan yang sama untuk menjadi contoh atau untuk menangani masyarakat dalam penyidikan survei akan disampaikan. Teknik pengumpulan informasi menggunakan menggunakan wawancara, observasi dan dokumentasi. Metode tersebut digunakan Untuk melihat hasil perkembangan sosial anak melalui teman sebaya. Metode analisis informasi dipakai merupakan analisis deskriptif merupakan pengukuran yang memiliki tugas untuk memilah dan membedah informasi berupa angka (Ghozali, 2018).

\section{Hasil dan Pembahasan}

Berdasarkan pada hasil analisi yang sudah dilakukan, maka dapat dinyatakan bahwa anak B4 di TK Negeri 01 Sangir Solok Selatan belum memiliki pengembangan sosial yang begitu baik dengan teman 
sebaya dan lingkungan sekitarnya. Hal tersebut terlihat dari beberapa penemuan di lapangan. Pertama keterbukaan terhadap teman sebaya. Keterbukaan anak dengan teman sebaya yang ada di B4 belum begitu berkembang. Hal ini dapat dilihat saat di dalam kelas ada anak yang suka menyendiri. Contohnya salah satu siswa yang suka duduk sendiri dan melamun berbeda dengan teman yang lain dengan sangat bahagia saat duduk bersama. Teman sebaya dalam pengembangan sosial anak sangat berperan sebagai tempat sosialisasi yang sangat membantu membentuk prilaku dan keyakinan pada anak, dengan adanya keyakinan dalam diri anak yang akan didapatnya dari teman sebaya akan memberikan manfaat dan pengaruh yang besar bagi pengembangan sosial anak (Ramadhani \& Fauziah, 2020).

Kedua, mau bermain bersama teman sebaya. Anak usia dini kalau bermain biasanya suka bersama teman dan berbagi mainan yang baru dengan teman sebaya yang memberikan komunikasi dan kebahagian dengan teman yang berada di satu ruangan, tetapi anak B4 cenderung suka bermain sendirisendiri dengan mainan yang telah dipilihnya dan duduk di tempat masing-masing yang dianggap nyaman tanpa menghiraukan teman disekitar. Bermain merupakan salah satu kebutuhan anak yang harus terpenuhi, karena anak usia dini sedang dalam masa keemasan dimana perkembangan dan pertumbuhan anak sedang berkembang sangat pesat (Rachmi \& Urpiah, 2020; Rahmadianti, 2020b). Dengan bermain anak akan sering berkomunikasi dengan lingkungan sekitarnya yang membuat perilaku sosial anak berkembang dengan baik. Maka dari itu lingkungan sekitar anak harus banyak memberi stimulus pada anak agar perkembangan anak berkembang dengan optimal, stimulus yang diberikan dapat melalui bermain

Ketiga, berusaha melakukan kontak sosial dengan teman sebaya. Sikap ini tidak terlihat pada anak B4, karena anak B4 suka duduk menyendiri dan melamun. Hal ini menimbulkan tidak ada usaha untuk bersosialisasi dengan teman lainnya. Namun beberapa anak sudah berusaha untuk melakukan kontak sosial pada teman sebaya yang ada di dekatnya. Interaksi yang baik antara anak dengan lingkungannya sangat penting karena dapat memberikan banyak perasaan, pengalaman, dan pembelajaran secara sosial dan emosional sehingga memungkinkan anak untuk memiliki tingkat perkembangan sosial-emosional yang tinggi (Gunarsih, 2016; Rahmawati \& Latifah, 2020). Anak yang terbiasa berinteraksi dengan teman dengan cukup intens dan terjalin kedekatan akan membuat anak belajar secara langsung mengenai kemampuan mengelola emosi, mengontrol diri, dan bertindak yang tepat sesuai dengan situasi dan kondisi . Maka dari itu, sangat penting untuk mengajarkan anak berinteraksi dengan teman sebayanya. Dengan melihat teman sebayanya anak akan mempelajari pola prilaku yang digunakan untuk menyesuaikan diri terhadap situasi sosial.

Keempat, kedekatan hubungan individu. Berdasarkan hasil observasi anak B4 tidak begitu akrap dengan teman yang lain seperti di dalam kelas maupun di luar kelas, sebagian dari siswa belum menunjukkan adanya kedekatan hubungan antar individu, akan tetapi beberapa anak sudah mempunyai kedekatan individual dengan teman yang berada di luar kelas dan di dalam kelas terjalin baik. Memiliki hubungan yang baik dengan lingkungan. Disaat berada di lingkungan teman yang bukan satu kelas anak B4 mereka hanya terdiam dan melamun di dekat teman yang lain tetapi seorang anak B4 begitu bahagia berada di lingkungan teman yang bukan satu kelas tampak kebahagian nya di wajah dengan tersenyum pada teman yang lain sambil senam. Contohnya kenzi yang sangat bergembira saat maju kedepan dengan perwakilan kelas lain untuk menuntun senam dengan teman yang berbeda kelas dengan dia. Teman sebaya juga memberikan dukungan fisik yaitu dengan memberikan sumber daya dan bantuan saat di butuhkan (Andangjati et al., 2021; Ramadhani \& Fauziah, 2020).

Berdasarkan pembahasan tersebut, Di TK Negeri 01 Sangir Solok Selatan khususnya di lokal B4 belum semua anak yang mampu dalam bersosialisasi dengan teman sebayanya. Hal tersebut menunjukkan perkembangan sosial seseorang anak sangat dipengaruhi oleh peran teman sebaya. Jika salah satu anak berbuat baik kepada temannya sehingga teman yang lain pun senang dengannya dan hal itu dilihat oleh anak yang lain dan akan mencontoh sikap dari teman nya tersebut. Penelitian ini menunjukkan teman sebaya sangat dibutuhkan anak untuk membantunya dalam pengembangan berhubungan sosial, anak yang pendiam akan terbuka terhadap temannya dan anak yang kurang percaya diri akan memperoleh dukungan oleh temannya, sehingga akan mengurangi tidak kepercayaan diri anak tersebut. Temuan ini diperkuat dengan temuan penelitian lain yang menyatakan bahwa hal yang dapat membantu anak dalam beradaptasi atau penyesuaian diri yaitunya kehadiran teman sebaya (Andangjati et al., 2021; Ramadhani \& Fauziah, 2020). Teman sebaya juga memberikan dukungan fisik yaitu dengan memberikan sumber daya dan bantuan saat dibutuhkan (Musyarofah, 2018; Rahmadianti, 2020b; Saputro \& Pardiman, 2012). Maka, teman sebaya sangat membantu terhadap pengembangan sosial anak yang memberikan pengaruh besar dalam diri seorang anak yang menjadi suatu kekuatan bagi anak B4 di TK negeri 01 sangir solok selatan. 


\section{Simpulan}

Pengembangan sosial anak dengan teman sebaya sangat membatu dalam pengembangan sosial dengan masing-masing anak. Hal ini dapat dilihat di saat anak mampu beradaptasi atau menyesuaikan diri di lingkungan sekolah. Kehadiran teman sebaya memberikan suatu kekuatan dalam diri anak untuk bersosialisasi. Teman sebaya sangat mempengaruhi pengembangan sosial anak dengan lingkungan di sekitar nya. Direkomendasikan pada guru dan kepala sekolah serta pihak yang terkait di TK Negeri 01 Sangir Solok Selatan agar dapat terus membantu pengembangan sosial anak sehingga tidak ditemukan lagi anak yang mengalami masalah dalam pengembangan sosialnya. Penelitian ini hanya membahas pengembangan sosial anak dengan teman sebaya di Taman kanak-kanak, penelitian selanjutnya dapat mengembangkan lebih dalam lagi mengenai pengembangan sosial anak dengan teman sebaya. Implikasi penelitian ini diharapkan dapat menjadi evaluasi dalam mengembangkan hubungan sosial anak dengan teman sebaya.

\section{Daftar Rujukan}

Agustin, M. (2020). Tipikal Kendala Guru PAUD dalam Mengajar pada Masa Pandemi Covid 19 dan Implikasinya. Jurnal Obsesi : Jurnal Pendidikan Anak Usia Dini, 5(1), 334-345. https://doi.org/10.31004/obsesi.v5i1.598.

Andangjati, M. W., Soesilo, T. D., \& Yustinus Windrawanto. (2021). Hubungan Antara Interaksi Sosial Teman Sebaya dengan Penerimaan Sosial Siswa Kelas XI. Jurnal Mimbar Ilmu, 26(167-173). https://doi.org/10.23887/mi.v26i1.33360.

Cakra, G., Dantes, N., Widiartini, K., Pendidikan, E., Pasca, P., \& Universitas, S. (2016). Pengaruh Penggunaan Metode Pembelajaran Bermain Peran Terhadap Sikap Sosial Dan Kemampuan Berbicara Bahasa Indonesia Siswa Kelas Vi Sd N 29 Dangin Puri Tahun Pelajaran 2014 / 2016. EJournal Program Pascasarjana Universitas Pendidikan Ganesha, 5(1), 1-10. https://doi.org/10.23887/jpepi.v5i1.1579.

Fadhilah, N., \& Mukhlis, A. M. A. (2021). Hubungan Lingkungan Keluarga, Interaksi Teman Sebaya Dan Kecerdasan Emosional Dengan Hasil Belajar Siswa. Jurnal Pendidikan, 22(1), 16-34. https://doi.org/10.33830/jp.v22i1.940.2021.

Ghozali, I. (2018). Aplikasi Analisis Multivariate dengan Program IBM SPSS 25. Badan Penerbit Universitas Diponegoro.

Gunarsih, F. D. (2016). Hubungan Interaksi Sosial, Konsep Diri, Dan Kecerdasan Emosional Terhadap Prestasi Belajar Matematika Siswa Kelas VIII SMP Negeri DI Kecamatan Pituruh. EKUIVALEN, 20(2), 211-216. https://doi.org/10.37729/ekuivalen.v20i3.2901.

Izza, H. (2020). Meningkatkan Perkembangan Sosial Anak Usia Dini melalui Metode Proyek. Jurnal Obsesi : Jurnal Pendidikan Anak Usia Dini, 4(2), 951. https://doi.org/10.31004/obsesi.v4i2.483

Junanto, S., \& Kusna, N. A. A. (2018). Evaluasi Program Pembelajaran di PAUD Inklusi dengan Model Context, Input, Process, and Product (CIPP). Inklusi, 5(2), 179. https://doi.org/10.14421/ijds.050202.

KhoiruzzadiM, BarokahM, \& KamilaA. (2020). Upaya Guru Dalam Memaksimalkan Perkembangan Kognitif, Sosial dan Motorik Anak Usia Dini. JECED : Journal of Early Childhood Education and Development, 2(1), 40-51. https://doi.org/10.15642/jeced.v2i1.561.

Maola, P., \& Lestari, T. (2021). Pengaruh Gadget terhadap Perkembangan Sosial Anak Sekolah Dasar. Journal of Education, Psychology and Counseling, 3(1), 219-225. https://ummaspul.ejournal.id/Edupsycouns/article/view/1403.

Mardiah, L. Y., \& Ismet, S. (2021). Dampak Pengasuhan Otoriter Terhadap Perkembangan Sosial Anak. JCE (Journal of Childhood Education), 5(1), 82-95. https://doi.org/10.30736/jce.v5i1.497.

Meilanie, R. S. M. (2020). Survei Kemampuan Guru dan Orangtua dalam Stimulasi Dini Sensori pada Anak Usia Dini. Jurnal Obsesi: Jurnal Pendidikan Anak Usia Dini, 5(1), 958-964. https://doi.org/10.31004/obsesi.v5i1.741.

Musyarofah, M. (2018). Pengembangan Aspek Sosial Anak Usia Dini Di Taman Kanak-Kanak Aba Iv Mangli Jember Tahun 2016. INJECT (Interdisciplinary Journal of Communication), 2(1), 99. https://doi.org/10.18326/inject.v2i1.99-122.

Negara, I. P. B. J., Suniasih, N. W., \& Sujana, I. W. (2019). Determinasi Disiplin Belajar Dan Interaksi Sosial Terhadap Pemahaman Konsep Ips Siswa Kelas V. Media Komunikasi FPIPS, 18(2), 87-96. https://doi.org/10.23887/mkfis.v18i2.22243.

Pebriana, P. H. (2017). Analisis Penggunaan Gadget Terhadap Kemampuan Interaksi Sosial Anak Usia Dini. Jurnal Obsesi: Journal of Early Childhood Education, 1(1). https://doi.org/https://doi.org/10.31004/obsesi.v1i1.26. 
Rachmi, T., \& Urpiah, S. (2020). Penerapan Bermain Bebas Dalam Mengembangkan Kemampuan Sosial Anak Usia 5-6 Tahun Di Tk. Mekarjaya Kec. Sepatan Kab. Tangerang. Ceria: Jurnal Program Studi Pendidikan Anak Usia Dini, 9(1), 22-29. https://doi.org/10.31000/ceria.v12i1.2856.

Rahmadianti, N. (2020a). Pemahaman Orang Tua Mengenai Urgensi Bermain Dalam Meningkatkan Perkembangan Sosial Anak Usia Dini. Early Childhood: Jurnal Pendidikan, 4(1), 57-64. https://doi.org/10.35568/earlychildhood.v4i1.717.

Rahmadianti, N. (2020b). Pemahaman Orang Tua Mengenai Urgensi Bermain Dalam Meningkatkan Perkembangan Sosial Anak Usia Dini. Early Childhood: Jurnal Pendidikan, 4(1), 57-64. https://doi.org/10.35568/earlychildhood.v4i1.717.

Rahmawati, M., \& Latifah, M. (2020). Penggunaan Gawai, Interaksi Ibu-Anak, Dan Perkembangan SosialEmosional Anak Prasekolah. Jur. Ilm. Kel. \& Kons., 13(1), 75-86. https://doi.org/10.24156/jikk.2020.13.1.75.

Ramadhani, P. R., \& Fauziah, P. Y. (2020). Hubungan Sebaya dan Permainan Tradisional pada Keterampilan Sosial dan Emosional Anak Usia Dini. Jurnal Obsesi : Jurnal Pendidikan Anak Usia Dini, 4(2), 1011. https://doi.org/10.31004/obsesi.v4i2.502.

Saputro, S. T., \& Pardiman, P. (2012). Pengaruh Disiplin Belajar Dan Lingkungan Teman Sebaya Terhadap Prestasi Belajar Mahasiswa Program Studi Pendidikan Akuntansi Angkatan 2009 Fakultas Ekonomi Universitas Negeri Yogyakarta. Jurnal Pendidikan Akuntansi Indonesia, 10(1), 78-97. https://doi.org/10.21831/jpai.v10i1.923.

Sirois, M.-S., Bernier, A., \& Lemelin, J.-P. (2019). Child temperamental anger, mother-child interactions, and socioemotional functioning at school entry. Early Childhood Research Quarterly, 47, 30-38. https://doi.org/10.1016/j.ecresq.2018.10.005.

Sukatin, Q. Y. H., Alivia, A. A., \& Bella, R. (2020). Analisis Psikologi Perkembangan Sosial Emosional Anak Usia dini. Bunayya: Jurnal Pendidikan Anak, 6(2), 156-171. https://jurnal.arraniry.ac.id/index.php/bunayya/article/view/7311/4306.

Sum, T. A., \& Taran, E. G. M. (2020). Kompetensi Pedagogik Guru PAUD dalam Perencanaan dan Pelaksanaan Pembelajaran. Jurnal Obsesi: Jurnal Pendidikan Anak Usia Dini, 4(2), 543. https://doi.org/10.31004/obsesi.v4i2.287.

We, A. Y., \& Fauziah, P. Y. (2020). Tradisi Kearifan Lokal Minangkabau "Manjujai” untuk Stimulasi Perkembangan Anak Usia Dini. Jurnal Obsesi : Jurnal Pendidikan Anak Usia Dini, 5(2), 1339-1351. https://doi.org/10.31004/obsesi.v5i2.660.

Yanti, Y., \& Marimin. (2017). Pengaruh Motivasi, Lingkungan Keluarga, Dan Teman Sebaya Terhadap Kedisiplinan Siswa. Economic Education Analysis Journal, 6(2), 329-338..

Yuniarni, D. (2016). Peran Paud Dalam Mengoptimalkan Tumbuh Kembang Anak Usia Dini Demi Membangun Masa Depan Bangsa. Jurnal Visi Ilmu Pendidikan, 8(1), 1-13. https://doi.org/10.26418/jvip.v8i1.27370. 